\title{
PEFFORMANCE AND EMISSION EVALUATION OF DIRECT INEJCTION DIESEL ENGINE USING CANOLA, SESAME BIODIESELS WITH N-BUTANOL
}

\author{
PRASAD K. Hari 1* ${ }^{*}$, SRINIVASAN C. Ananda ${ }^{2}$, KUMAR K. Praveen ${ }^{3}$ \\ ${ }^{I}$ Research scholar, Annamalai University (Assistant Professor in RVR \&JCCE) \\ e - mail: hariprasad.krr@gmail.com \\ ${ }^{2}$ Associate Professor in Mechanical Engg., Annamalai University, Chidambaram \\ (Deputed to TPGIT, Vellore) e - mail: anandsrinivasa@yahoo.com \\ ${ }^{3}$ Associate Professor in RVR \& JC College of Engineering, Guntur e - mail: kpraveen717@gmail.com
}

\begin{abstract}
Biodiesels from vegetable oils are also gaining momentum as a encouraging fuels which acts as alternative for agricultural diesel engines. Even though there is a slight penalty in the performance parameters by the usage of vegetable biodiesel fuels in diesel engines because of their high viscosity, there is considerable reduction in emissions which is dominant factor from the environmental perspective. In the present experimental work four fuels Canola (20\% Canola oil plus 80\% Diesel) biodiesel (B20C),Sesame (20\% Sesame oil plus $80 \%$ Diesel) biodiesel (B20S) ,B20C blended with 5\% n-butanol(B20C5B) and B20S is blended with 5\% nbutanol(B20S5B) have tried as an alternative fuels to the Diesel. In the primitive stage tests were supervised on diesel engine with diesel. Thereafter in the second stage, tests were directed at identical operating conditions by using B20C, B20S and their blends as biodiesels. The engine important performance parameters brake thermal efficiency (BTE) and brake specific fuel consumption (BSFC) and also the emission characteristics hydrocarbons (HC), carbon monoxide (CO), smoke opacity and nitrogen oxides (NOx) are evaluated. The results are contrasted with respect on base line data (diesel). From the experimental readings it was observed that the BTE of B20C, B20S, B20C5B and B20S5B at 100\% load decreased by $2.64 \%, 1.9 \%, 1.41 \%$ and $0.94 \%$ respectively, relative to diesel (D). At maximum loading condition BSFC for diesel,B20C,B20S,B20C5B and B20S5B are 0.254, $0.284,0.273,0.270$ and $0.260 \mathrm{~kg} / \mathrm{kWh}$. Overall, it is concluded that the emission characteristics of $\mathrm{HC}, \mathrm{CO}$ and Smoke opacity are dropped for all tested biodiesels when compared to diesel fuel.
\end{abstract}

KEYWORDS: B20C, B20S, B20C5B, B20S5B, Hydrocarbons, CO emissions, $\mathrm{N}_{\mathrm{Ox}}$

\section{Introduction}

An alternative name for diesel engine is Compression ignition (CI) engines and it has wide applications in trucks, commercial vehicles, agricultural pumping sets etc., because of their high power outturn and low tailpipe emissions. Despite of little hydrocarbons (HC) , carbon monoxide (CO) emissions in $\mathrm{CI}$ engine as compared to petrol engines, there is a problem with content of particulate matter $(\mathrm{PM})$ and nitrogen oxides $\left(\mathrm{NO}_{\mathrm{x}}\right)[1,2]$. To solve this, researchers are constantly trying to search for alternative to diesel fuel which should be economical, environmental friendly and abundantly available resource as biodiesel [3]. Many researchers have tried with many biodiesels derived from different feedstock like seeds of Karanja, Mahua, Neem, Jatropha and Tamarind oils. Biodiesel is a encouraging permanent alternative fuel in CI engines as most of the properties close to diesel and have cleaner combustion characteristics. Biodiesels added with diesel in suitable proportions showed better performance in CI engines including low particulate matter (PM)[4,5]. High viscosity and density are the detrimental factors for pure biofuels. So they can't be used in CI engines directly. The certainty lies with the function of hard deposits that may come from fuel injector tips accumulates over the piston rings causing premature wear and failure of the engine. It may also lead to nozzle clogging and corrosion on plastic pipelines $[6,7]$. Therefore biofuels mingled in pure diesel with suitable 
amounts and can broadly used in engines which runs on diesel. Using canola oil methyl ester as biodiesel Ileri and his group design their experimentation and reported the effect of antioxidants on the performance of the engine. It has come to know that antioxidant addition had no negative impact on the properties of COME fuel mixed with diesel. In comparison with pure diesel both canola oil and palm oil blends are altered in emission characteristics, where as power output from the engine decreased mildly in CI engines. Some other researchers like Ozsezen[9] and Banapurmath [10] under control parameters, experiments are designed on CI engine in which Marotti oil blend is used as fuel. It is noticed that as the diesel proportion in the blends decreased, both tail pipe gas temperature and BTE are dropped. Water melon seed oil methyl ester has blend in diesel Pannerselvam [11] group has studied that there is a drop in BTE as well as emission characteristics are reduced.

Ulusoy et al.,[12] compared the performance of CI engine with Sunflower oil methyl ester(SFME) with conventional diesel. It is concluded that at all engine speeds the $\mathrm{CO}, \mathrm{HC}$ and soot emissions of SFME biodiesel were less than that of diesel. In a probability study of crude rice brawn methyl ester (RBME) biodiesel fuel for a stationary compression ignition engine [13], it is came to know that the quality of RBME biodiesel was marginally superior that that of natural diesel. BTE and unburned hydrocarbons (UBHC), particulate matter and $\mathrm{CO}$ are marginally decreased and slight increment observed in NOx emissions.

Ramadhas et al.,[14] conducted performance tests on diesel engine using Rubber seed methyl ester (RSOME) biodiesel with varying proportions in diesel and obtained maximum BTE of $28 \%$ along with low emissions and BSFC at B10 blend. Tamilselvan and Nallusamy [15] used pine oil blends with diesel in a CI engine and concluded that BTE and emissions are marginally decreased along with slight increment in NOx emissions. It was also obtained that with $100 \%$ pine oil blend maximum thermal efficiency results and also reduced emissions. This is because of lowest kinematic viscosity for $100 \%$ pine oil when compared with diesel. Chribik, A., et al., [16] discovered that burning synthesis gas reduces performance by about 5\% while increasing mass hourly onsumption by $120 \%$. Kapilan, N., et al., [17] observed that the fuel mixture results in engine performance close to diesel operation at the higher injector nozzle opening pressure. Few researchers reported that fluid injection has a significant impact on internal flows [18].

Jun Cong ge et al., [19] have used Canola oil biodiesel as an alternative fuel to the diesel in $\mathrm{CI}$ engine at various blend levels. Out of the blends tried COB20 blend is qualified as best alternative fuel because of its high performance in CI engines. The excess oxygen atoms in COB20 play a major role in reduction of exhaust emissions. However their presence encourages combustion, increases temperature of combustion products which may leads to increased NOx emission levels. By using exhaust gas recirculation (EGR) technology NOx can be reduced. Punitharani, K., et.al., [20] study looked at the effect of Exhaust Gas Recirculation (EGR) on a 4S, single cylinder, DI diesel engine using lastic oil/Diesel blends P10 (10\% plastic oil \& 90\% diesel in volume), P20, and P30 at various EGR rates, and the results showed that the P20 blend had the lowest NOxemission quantity.

To examine the combustion and performance characteristics of diesel engine Kumar et.al[21] reported the various applications of additives in biodiesel at various levels. They looked at the effect of additives such as nano ,oxygenate andantioxidant additives to enhance the efficiency of biodiesel. From a thorough analysis of several research results, they examined that the benefit of additives showed improvement in the parameters of combustion and substantial decrement in the emissions of engines. Butanol has a higher amount of cetane and the corrosion caused by butanol was much lower than methanol and ethanol. Upon comparing with other alcohols Broukhiyan and Lestz [22] reported that butanol can be ignited more easily and quickly. Fuel efficiency of the engine is improved because of addition of 
butanol and it is reported by Balamurugan and Nalini [23]. The effects of butanol on engine performance characteristics at 5\%,10\% and 20\% combined with diesel fuel were studied by Byunchul et al and reported that carbon monoxide emissions rised due to bigger concentrations of butanol[24]. The characteristics of diesel engines observed by the dogan et.al considering the effect of butanol [25]. They concluded it increases BTE and hydrocarbon emissions ( HC) and significantly reducing the opacity of smoke and CO emissions compared to diesel fuel. In direct injection diesel engine using four different combinations of 1-butanol / diesel and 1pentanol / diesel engine Campos-Fernandez et al[26] reported that as compared to 1-pentanol / diesel blends, 1-butanol / diesel blends have slight decrease in BSFCs and also suggested 30\% butanol / diesel fuel and 25\%1-pentanol / diesel fuel blend as alternative diesel fuel with little importance.

Although, many researchers have been trying to search alternative fuels to diesel, a significant work on Canola and Sesame biodiesels was not found and detailed study on the performance of CI engine using these biodiesels is yet to undertaken. Even though, considerable literature on biodiesels exists, a concise and accurate literature report on these biodiesels is required. These two biodiesels from vegetable oils are also showing promising results and have good enough scope to fulfill the gap occurring because of depletion of fossil fuels. The present work spotlighted on the performance assessment of diesel engines using these biodiesels without any engine modifications.

\section{Experimental Procedure}

The tests were operated on a 4 stroke single cylinder naturally aspirated direct injection diesel engine (make Kirloskar TV1) which is united with eddy current dynamometer. After inspection and calibration of required instruments they are arranged to assess the performance of engine parameters and tail pipe emissions. A personal computer with Internal Combustion Enginesoft combustion software is coupled to the engine to note down the combustion and performance parameters. The engine tailpipe emissions like $\mathrm{CO}, \mathrm{HC}$ and NOx are carefully evaluatred using AVL 444N five gas analyzer and technical specifications are mentioned Table1.There after using AVL 437C smoke meter smoke opacity intension is acquired. Fig.1 depicts the experimental set up.

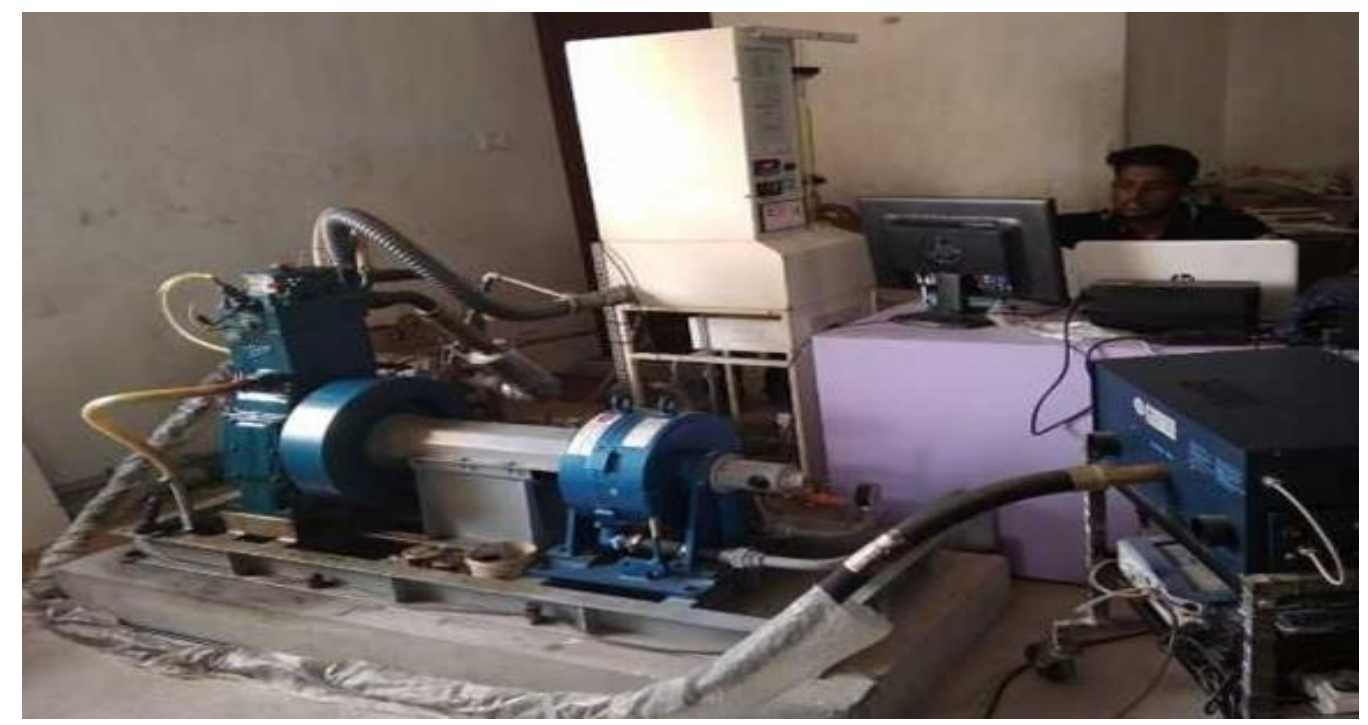

Fig. 1 Four stroke single cylinder Diesel Engine 
Table 1: Properties of Fuels

\begin{tabular}{cccc}
\hline Properties & Diesel & Canola & Sesame \\
\hline Density $\left(\mathrm{kg} / \mathrm{m}^{3}\right)$ & 840 & 885 & 882 \\
Sp. gravity & 0.84 & 0.85 & 0.82 \\
$\mathrm{~K}$ V $(\mathrm{c} \mathrm{St})$ at $40{ }^{0} \mathrm{C}$ & 3.5 & 4.2 & 5.34 \\
Flash point $(1 \mathrm{C})$ & 56 & 182 & 170 \\
Calorific value & 43000 & 39490 & 38836 \\
$(\mathrm{~kJ} / \mathrm{kg})$ & & & \\
\hline
\end{tabular}

\section{Results and Discussions}

Initially load test has been performed under various loads ranging from $0 \mathrm{kgf}$ to $18 \mathrm{kgf}$ at $4.5 \mathrm{kgf}$ interval maintaing a study engine speed of $1500 \mathrm{rpm}$. Then same tests repeated with Canola biodiesel (B20C) and Sesame biodiesel (B20S) fuels and its blends with n-butanol. The performance parameters were evaluated and emissions characteristics were reported and diverse performance graphs were plotted.

\subsection{Performance characteristics}

\subsubsection{Brake Thermal Efficiency (BTE)}

Fig. 2a depicts the alterations of the BTE with reference to the engine load for diesel, B20C, B20S, B20C5B and B20S5B. Diesel has the apical BTE, it has low viscosity as compared to tested fuels. Out of the all biodiesels examined B20S5B has the maximum BTE. Because of the addition of ignition enhancer, the improvement in brake thermal efficiency due to improved combustion has the effect of reducing viscosity. The BTE of B20C, B20S, B20C5B and B20S5B at $100 \%$ load decreased by $2.64 \%, 1.9 \%, 1.41 \%$ and $0.94 \%$ respectively, relative to diesel (D)

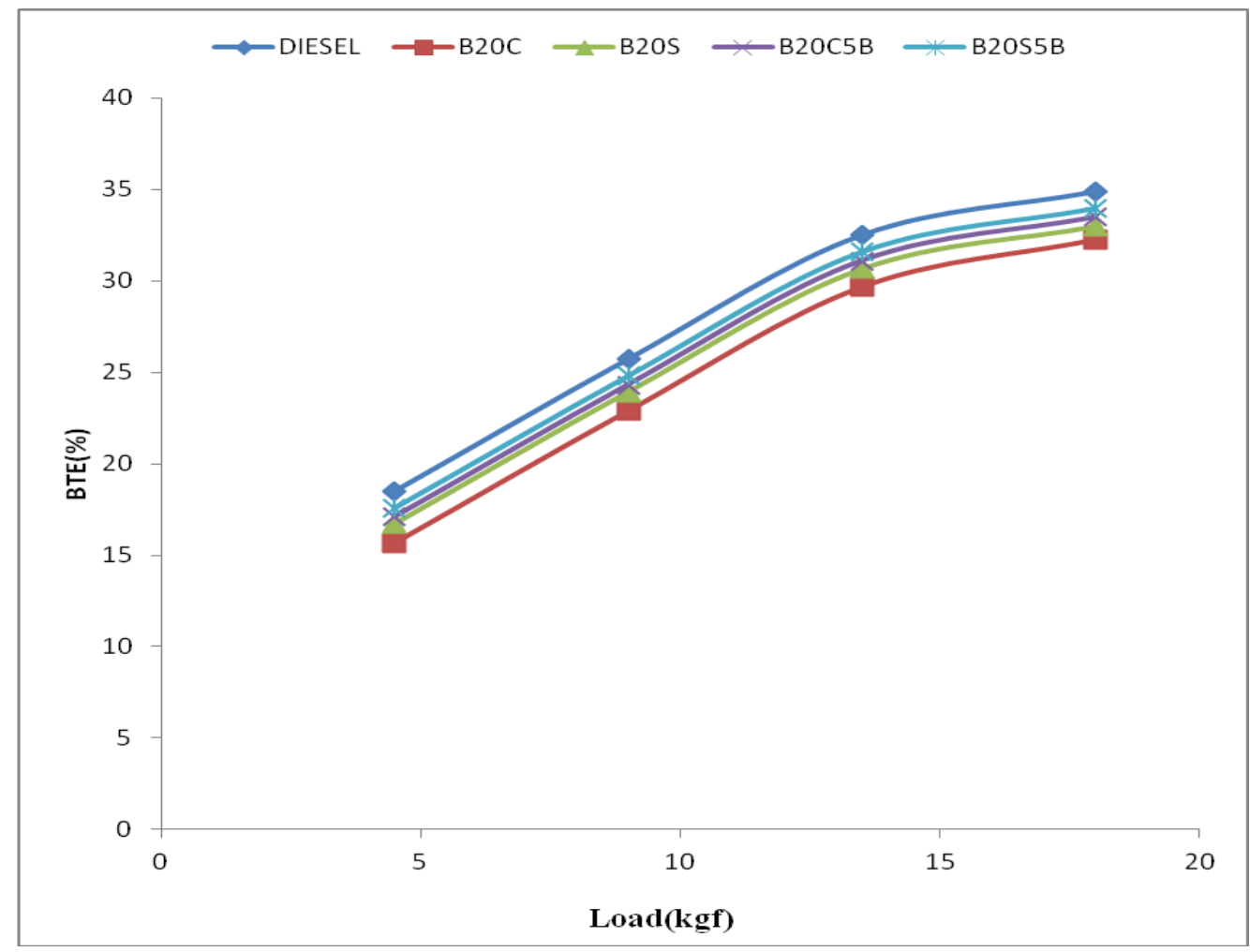

Fig. 2 Alteration of BTE against Load 


\subsubsection{Brake Specific Fuel Consumption(BSFC)}

Fig. 2b depicts the alterations of the BSFC variation against load for diesel, B20C, B20S, $\mathrm{B} 20 \mathrm{C} 5 \mathrm{~B}$ and B20S5B. BSFC is a function of viscosity, density and thermal energy content. From the plot it is noticed that as increment in load leads to decrement in BSFC for all fuels. At peak load condition, the BSFC readings are $0.254,0.284,0.273,0.270$ and $0.260 \mathrm{~kg} / \mathrm{kWh}$ for diesel, B20C, B20S, B20C5B and B20S5B biodiesels respectively. As a result of higher density there is a little rise in BSFC for biodiesel blends.

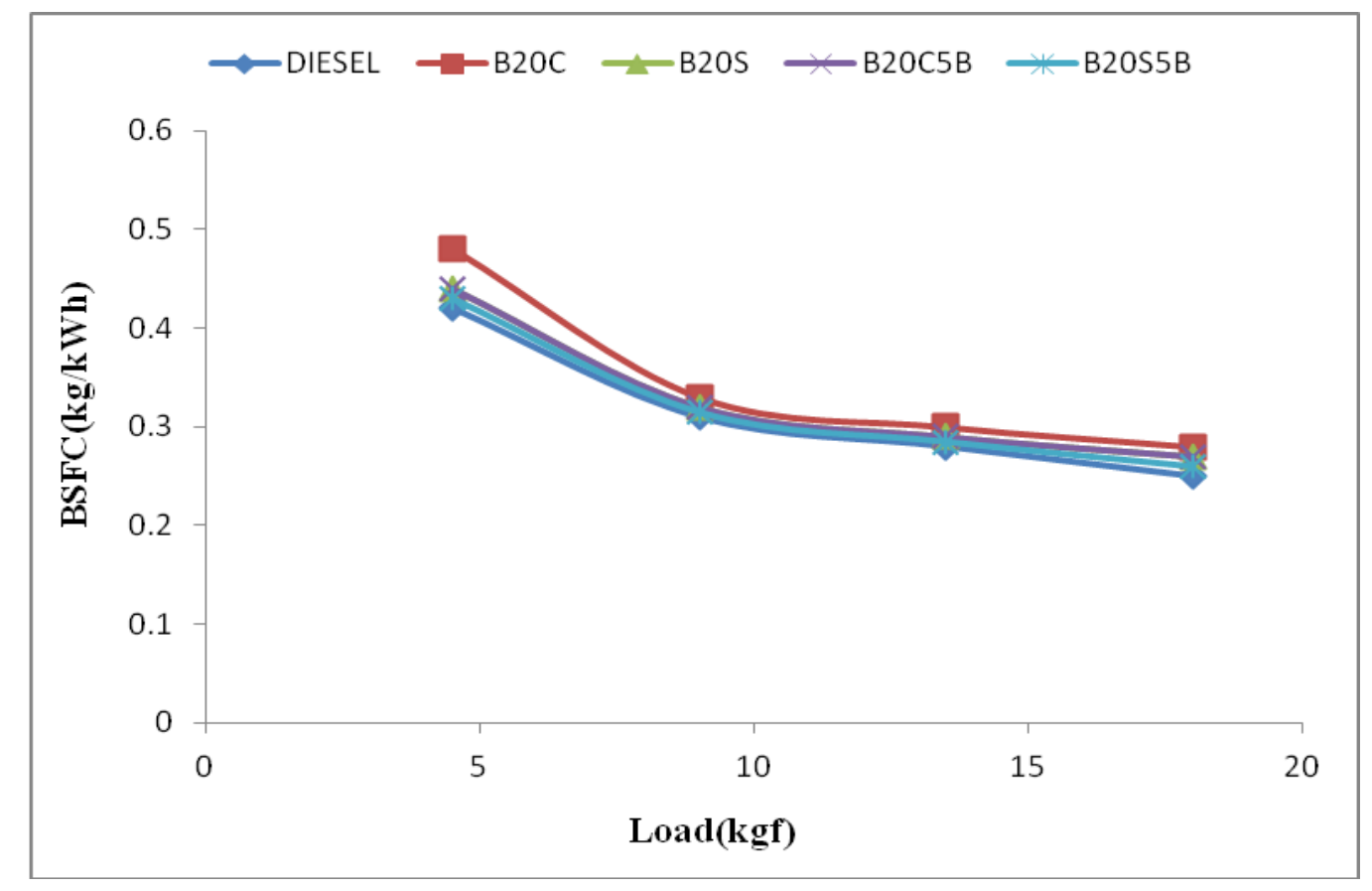

Fig. 3 Alteration of BSFC against Load

\subsection{Emission Characteristics}

\subsubsection{Hydrocarbon emissions (HC)}

Fig. 3a. Shows the alteration of HC emissions with engine load for diesel, B20C, B20S, B20C5B and B20S5B biodiesel. In the entire load operation B20S5B shows better results in contrast to hydrocarbon emissions. At peak load environment the $\mathrm{HC}$ emissions for diesel, B20C, B20S, B20C5B and B20S5B biodiesel blends are 96ppm, 68ppm, 52ppm, 59ppm and $44 \mathrm{ppm}$ respectively. This is as a result of the inherent greater existence of oxygen in B20S5B in contrast to diesel and other tested fuels which results in improved combustion.

\subsubsection{Carbon monoxide emissions (CO):}

The $\mathrm{CO}$ emissions rely on the fuel's properties along with time needed for whole combustion process. Various factors affecting carbon monoxide formation incorporate low oxygen content and atomization of poor fuel. From the figure it can be observed that at intermediate loads $\mathrm{CO}$ emissions decreased initially and later increased due to low cylinder temperature which restricts hydrocarbon combustion. $\mathrm{CO}$ emissions are increased at higher engine loads owing lean airfuel blend. Because of rich fuel-air mixture, the fuel is supplied with less oxygen content for full combustion and partial combustion is therefore achieved. 


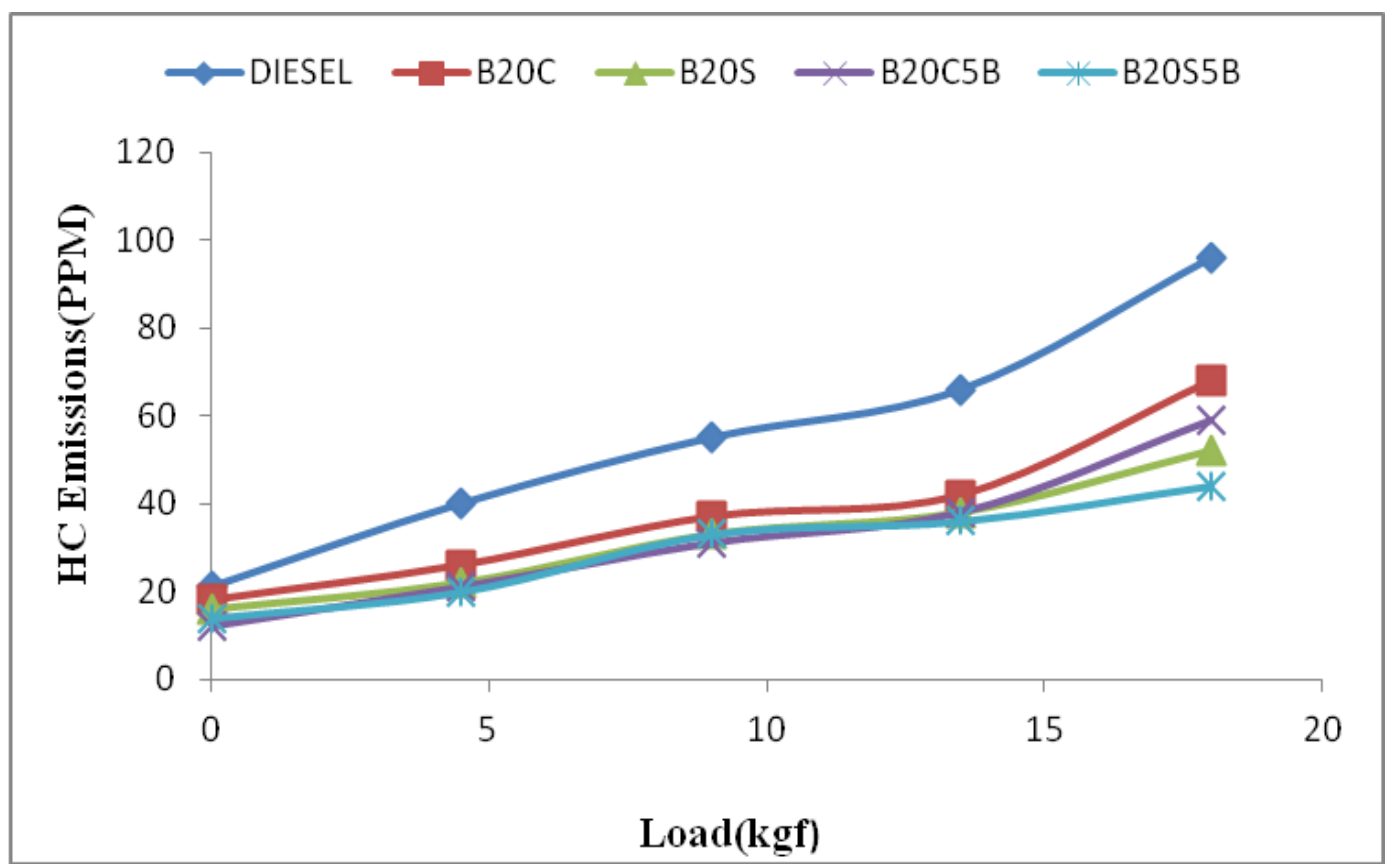

Fig. 4 Alteration of Hydrocarbon emissions against Load

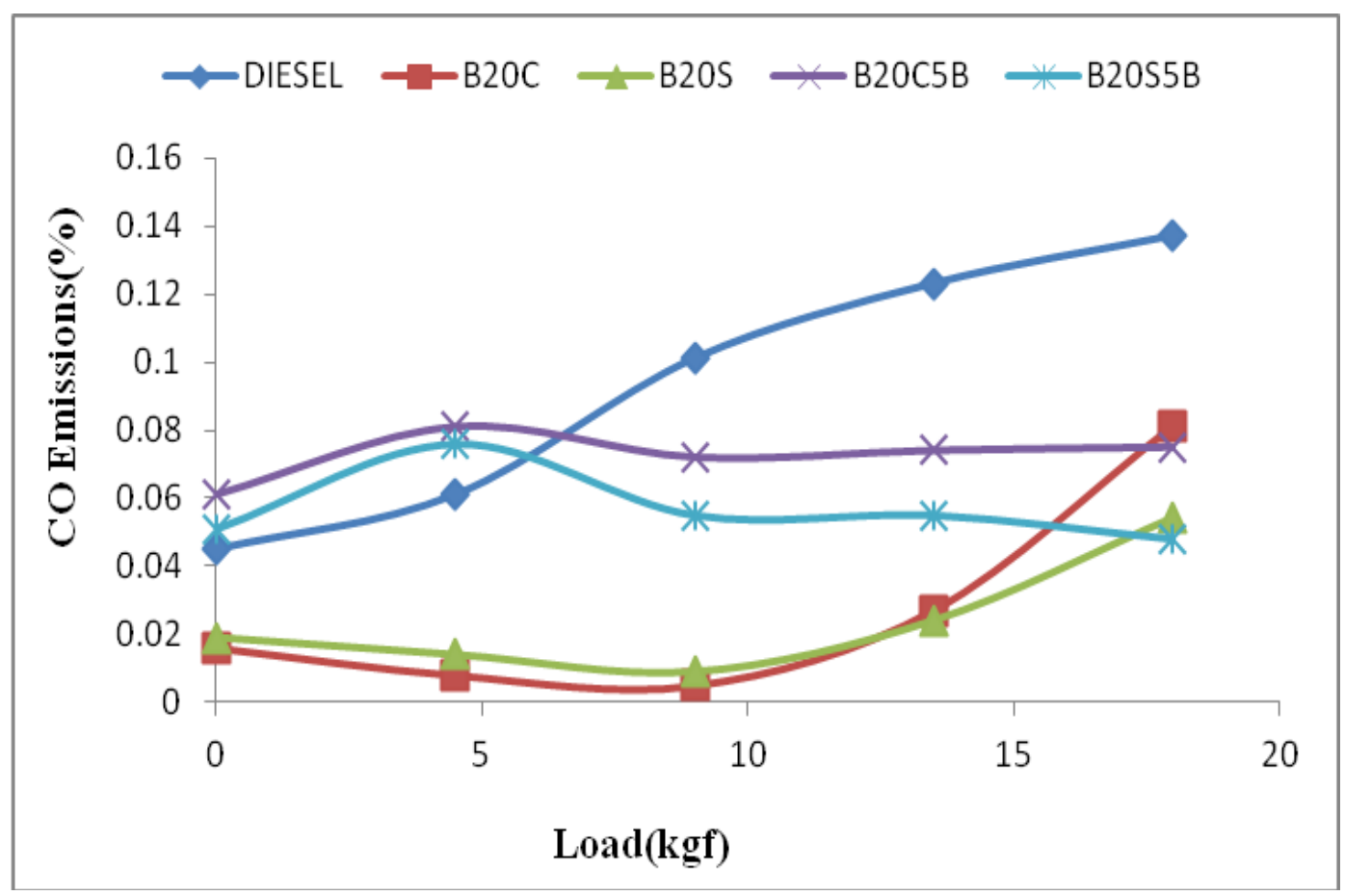

Fig. 5 Alteration of $\mathrm{CO}$ emissions against Load

\subsubsection{Nitrogen oxides emissions ( $\left.\mathrm{NO}_{\mathrm{x}}\right)$}

Fig.4.a. depicts the alteration of $\mathrm{NO}_{\mathrm{X}}$ emissions for diesel, B20C, B20S, B20C5B and $\mathrm{B} 20 \mathrm{~S} 5 \mathrm{~B}$ biodiesel according to the engine load. It was shown that $\mathrm{NO}_{\mathrm{x}}$ emissions were superior for B20S5B biodiesel blend with respect other fuels. The $\mathrm{NO}_{\mathrm{x}}$ emission of B20S5B blend was $1872 \mathrm{ppm}$ correlated to a value of $1791 \mathrm{ppm}$ for B20C5B, $1736 \mathrm{ppm}$ for B20S,1701ppm for B20C and $1656 \mathrm{ppm}$ for diesel. The emissions of oxides of nitrogen for biodiesel proportions were higher and nearer to diesel due to inherent oxygen, which promotes the better burning of 
fuel and elevated flame temperature even though a lower heating value of biodiesel proportions than base fuel.

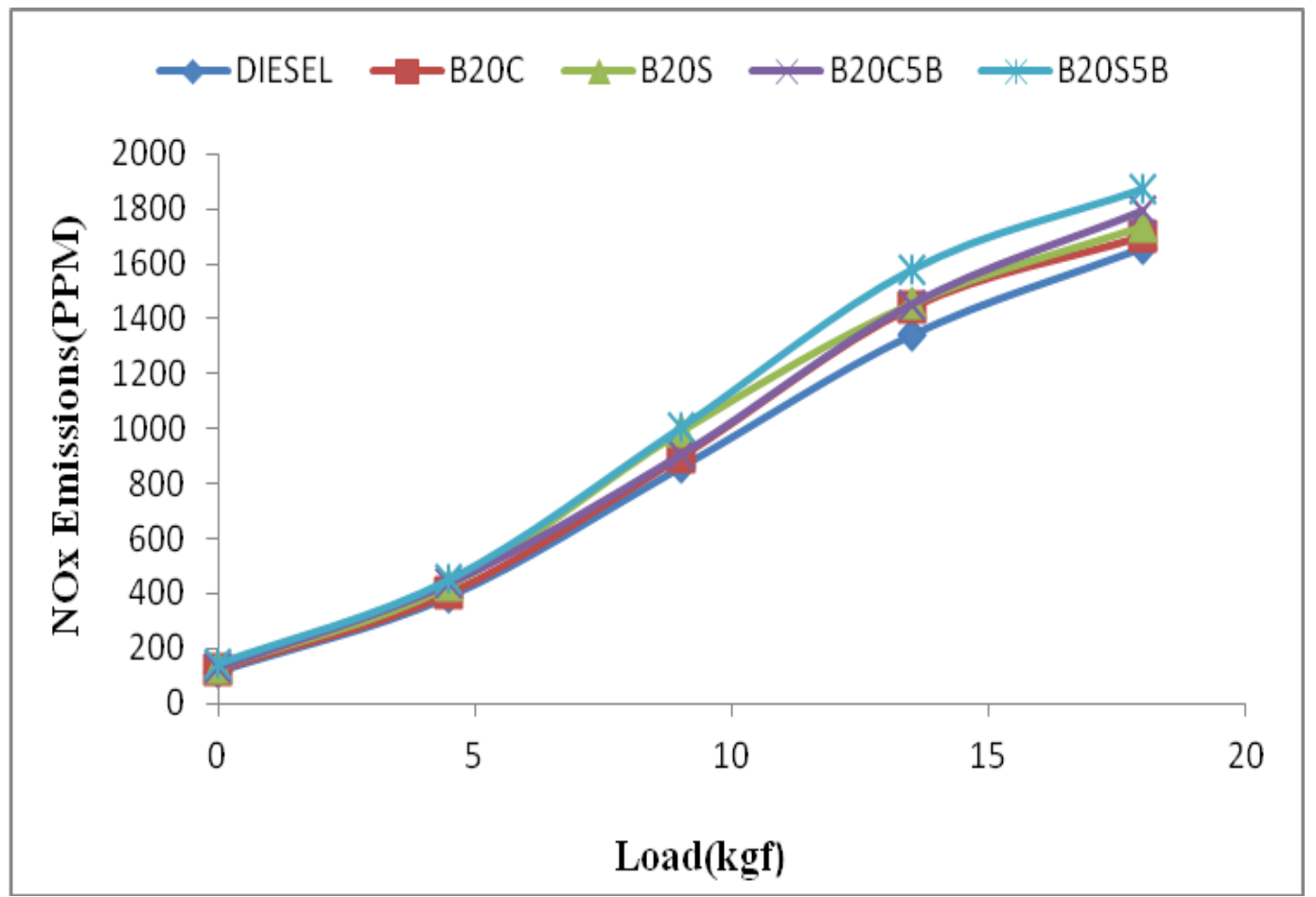

Fig. 6 Alteration of $\mathrm{NO}_{\mathrm{X}}$ emissions against Load

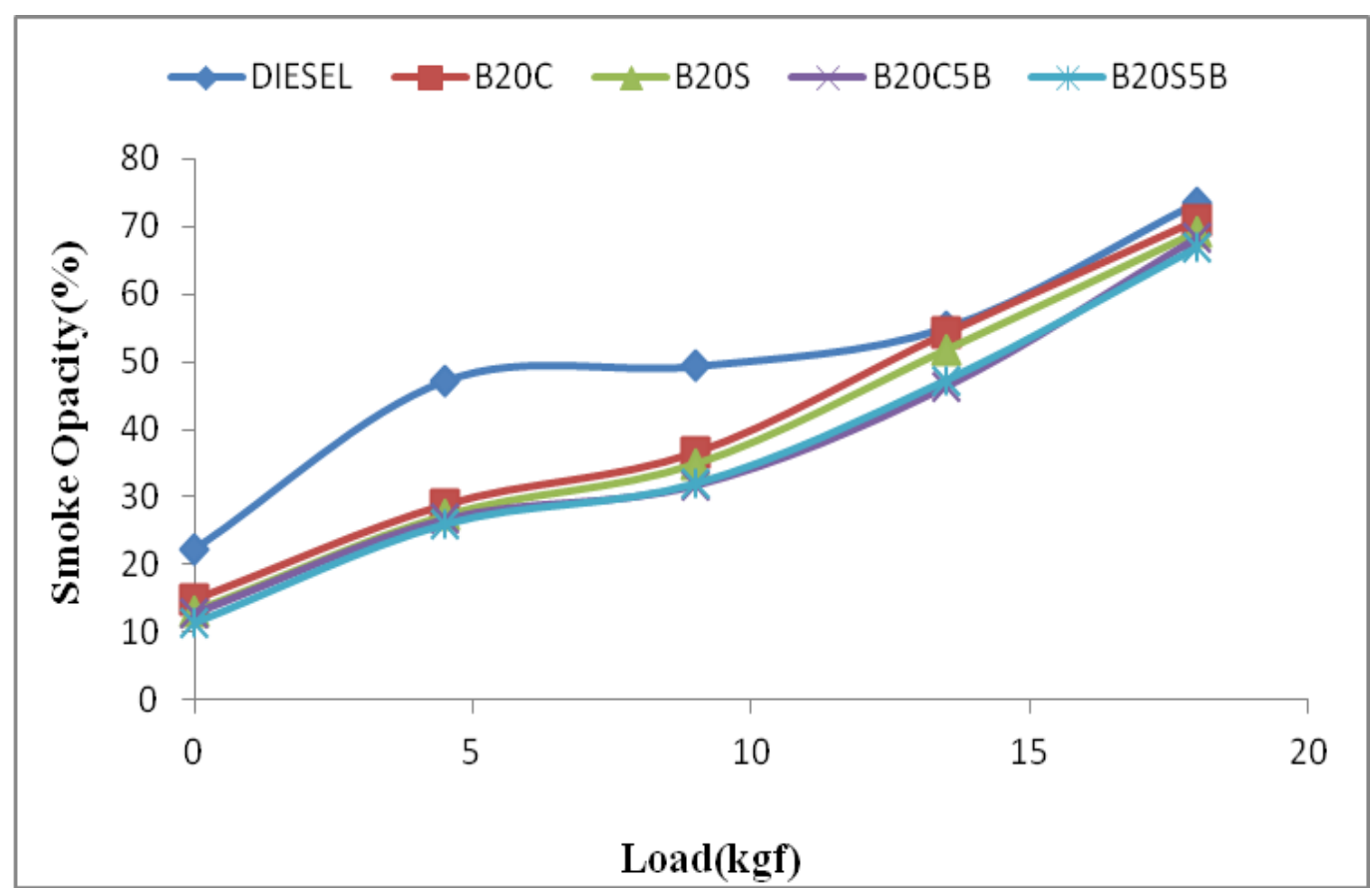

Fig. 7 Alteration of Smoke opacity against Load

\subsubsection{Smoke Opacity}

Alteration of smoke opacity with engine load for diesel, B20C, B20S, B20C5B and B20S5B biodiesels are illustrated in Fig.4.b. It is perceived that at lighter loads smoke opacity is 
considerably reduced for biodiesel when contrast to pure diesel. However as the load increases the difference in smoke opacity between tested biodiesels and pure diesel is marginal. Increased smoke emissions associated with increased load for the reason that high fuel consumption at peak loads. At peak loads of engine once more fuel get into the combustion chamber result in partial combustion of fuel and leads smoke emissions. The smoke opacity at $100 \%$ load for Diesel, B20C, B20S, B20C5B and B20S5B, was 73.6\%, 70.8\%, 69.2\% ,68.3\% and 66.8\% respectively.

\section{CONCLUSION}

The performance and emissions characteristics of direct injection diesel engine were evaluated with Canola (B20C), Sesame (B20S) and its blends with n-butanol B20C5B,B20S5B biodiesels and results are correlated with those of standard base fuel. The engine was able to operate without any modifications with the tested biodiesels. The main findings from the experiments are summarized as follows:

$>$ In contrast to diesel, B20C, B20S, B20C5B and B20S5B, have lower brake thermal efficiency. At peak load highest BTE is obtained with diesel is $34.88 \%$. The BTE of B20C, B20S, B20C5B and B20S5B, at 100\% load decreased by $2.64 \%, 1.9$ $\%, 1.41 \%$ and $0.94 \%$ respectively, relative to diesel

$>$ BSFC at maximum load condition for diesel is $0.254 \mathrm{~kg} / \mathrm{kWh}$, for B20C is 0.284 $\mathrm{kg} / \mathrm{kWh}, \mathrm{B} 20 \mathrm{~S}$ is $0.273 \mathrm{~kg} / \mathrm{kWh}, \mathrm{B} 20 \mathrm{C} 5 \mathrm{~B}$ is $0.270 \mathrm{~kg} / \mathrm{kWh}$ and B20S5B is 0.260 $\mathrm{kg} / \mathrm{kWh}$.

$>\mathrm{HC}, \mathrm{CO}$ and $\mathrm{PM}$ emissions of both B20C, B20S, B20C5B and B20S5B, were dropped as contrast to diesel. Among all biodiesels tested B20S5B is better results than other fuels regarding these emission levels.

$>\mathrm{NO}_{\mathrm{x}}$ emissions were higher for all biodiesels when contrasted to diesel. The B20S5B biodiesel has largest $\mathrm{NO}_{\mathrm{x}}$ emission at all loads when compared with remaining fuels.

As a summary Sesame (B20S5B) biodiesel could be suggested as an surrogate to diesel fuel in CI engines even though BTE value slightly decreased, SFC value almost same and exhaust emissions are considerably decreased with this biodiesel which is main consideration from the environmental point of view.

\section{REFERENCES}

[1] Heywood, J. B. “Combustion engine fundamentals”, 1ª Edição. Estados Unidos, 1988.

[2] Kegl, B., Kegl, M., Pehan, S. “Green diesel engines. Biodiesel Usage in Diesel Engines”, Springer-Verlag, London, 2013.

[3] Mahalingam, A., Munuswamy, D. B., Devarajan, Y., Radhakrishnan, S. "Emission and performance analysis on the effect of exhaust gas recirculation in alcohol-biodiesel aspirated research diesel engine", Environmental Science and Pollution Research 25(13), pp. 12641 - 12647, 2018.

[4] Kannan, D., Pachamuthu, S., Nabi, M. N., Hustad, J. E., Løvås, T. "Theoretical and experimental investigation of diesel engine performance, combustion and emissions 
analysis fuelled with the blends of ethanol, diesel and jatropha methyl ester", Energy conversion and management 53(1), pp. 322 - 331, 2012.

[5] Lin, B. F., Huang, J. H., Huang, D. Y. "Experimental study of the effects of vegetable oil methyl ester on DI diesel engine performance characteristics and pollutant emissions", Fuel 88 (9), pp. 1779 - 1785, 2009.

[6] Liaquat, A. M., Masjuki, H. H., Kalam, M. A., Fazal, M. A., Khan, A. F., Fayaz, H., Varman, M. "Impact of palm biodiesel blend on injector deposit formation", Applied energy 111, pp. $882-893,2013$.

[7] Chaikool, P., Intravised, K., Patsin, P., Laonapakul, T. "A study of effect of biodiesel on common-rail injection nozzle", SAE International Journal of Fuels and Lubricants 9(3), pp. $712-716,2016$.

[8] Ileri, E., Koçar, G. "Effects of antioxidant additives on engine performance and exhaust emissions of a diesel engine fueled with canola oil methyl ester-diesel blend", Energy Conversion and Management 76, pp. 145 - 154, 2013.

[9] Ozsezen, A. N., Canakci, M., Turkcan, A., Sayin, C. "Performance and combustion characteristics of a DI diesel engine fueled with waste palm oil and canola oil methyl esters", Fuel 88 (4), pp. 629 - 636, 2009.

[10] Banapurmath, N. R., Tewari, P. G., Hosmath, R. S. "Combustion and emission characteristics of a direct injection, compression-ignition engine when operated on Honge oil, HOME and blends of HOME and diesel", International Journal of Sustainable Engineering 1 (2), pp. 80 - 93, 2008.

[11] Panneerselvam, N., Murugesan, A., Vijayakumar, C., Subramaniam, D. "Performance, emissions and combustion characteristics of CI engine fuel with watermelon (Citrullus vulgaris) methyl esters", International Journal of Ambient Energy 38 (3), pp. 308 - 313, 2017.

[12] Ulusoy, Y., Arslan, R., Kaplan, C. "Emission characteristics of sunflower oil methyl ester", Energy Sources, Part A, 31(11), pp. 906 - 910, 2009.

[13] Saravanan, S., Nagarajan, G., Rao, G. L. N. "Feasibility analysis of crude rice bran oil methyl ester blend as a stationary and automotive diesel engine fuel", Energy for Sustainable Development 13(1), pp. 52 - 55, 2009.

[14] Ramadhas, A. S., Muraleedharan, C., Jayaraj, S. "Performance and emission evaluation of a diesel engine fueled with methyl esters of rubber seed oil", Renewable energy 30(12), pp. 1789 - 1800, 2005.

[15] Tamilselvan, P., Nallusamy, N. "Performance, combustion and emission characteristics of a compression ignition engine operating on pine oil", Biofuels, 6 (5 - 6), $273-281$. 2015.

[16] Chríbik, A., Polóni, M., Lach, J., Jančošek, L., Kunc, P., Zbranek, J. "Internal Combustion Engine Powered by Synthesis Gas from Pyrolysed Plastics", Strojnícky časopis - Journal of Mechanical Engineering 66 (1), pp. 37 - 46, 2016. DOI: 10.1515/scjme-2016-0009 
[17] Kapilan, N., Jullya, N. "Studies on improvement of performance of compression ignition engine fuelled with mixture of honge biodiesel and tire pyrolysis oil", Strojnícky časopis - Journal of Mechanical Engineering 68 (1), pp. 15 - 24, 2018. DOI: 10.2478/scjme2018-0002

[18] Mlkvik, M., Olšiak, R., Smolar, M. "Comparison of the Viscous Liquids Spraying by the Oig and the Oil Configurations of an Effervescent Atomizer at Low Inlet Pressures", Strojnícky časopis - Journal of Mechanical Engineering 66 (1), pp. 53 - 64, 2016. DOI: $10.1515 /$ scjme-2016-0011

[19] Ge, J. C., Yoon, S. K., Choi, N. J. "Using canola oil biodiesel as an alternative fuel in diesel engines: A review", Applied Sciences, 7 (9), 881, 2017.

[20] Punitharani, K., Parameshwaran, V. "Effect of exhaust gas recirculation on performance of a diesel engine fueled with waste plastic oil/diesel blends", Strojnícky časopis Journal of Mechanical Engineering 67 (2), pp. 91 - 100, 2017. DOI: 10.1515/scjme-20170022

[21] Kumar, M. V., Babu, A. V., \& Kumar, P. R. "The impacts on combustion, performance and emissions of biodiesel by using additives in direct injection diesel engine", Alexandria Engineering Journal 57(1), pp. 509 - 516, 2018.

[22] Broukhiyan, E. M. H., \& Lestz, S. S. "Ethanol fumigation of a light duty automotive diesel engine", (No. 811209), SAE Technical Paper, 1981.

[23] Balamurugan, T., Nalini, R. "Experimental investigation on performance, combustion and emission characteristics of four stroke diesel engine using diesel blended with alcohol as fuel”, Energy 78, pp. 356 - 363, 2014.

[24] Choi, B., Jiang, X., Kim, Y. K., Jung, G., Lee, C., Choi, I., Song, C. S. "Effect of diesel fuel blend with n-butanol on the emission of a turbocharged common rail direct injection diesel engine", Applied Energy 146, pp. 20-28, 2015.

[25] Doğan, O. "The influence of n-butanol/diesel fuel blends utilization on a small diesel engine performance and emissions", Fuel 90 (7), pp. 2467 - 2472, 2011.

[26] Campos-Fernández, J., Arnal, J. M., Gómez, J., Dorado, M. P. "A comparison of performance of higher alcohols/diesel fuel blends in a diesel engine", Applied energy 95, pp. $267-275,2012$. 